\title{
THE USES OF LEGISLATIVE COMMITTEES*
}

\author{
J. R. Mallory
}

Under our system of cabinet government it is the legislature which is the democratic nucleus, for the popularly elected legislature is the only part of government chosen by and responsible to the people. From this fact stems the most important function of the elected legislature, its function, in Walter Bagehot's words, as an electoral chamber. Under responsible government it is the elected commons which "chooses" the government by giving a government authority, by sustaining it and thus making stable government possible, and by withdrawing confidence from a government which no longer deserves to rule.

Legislation is therefore only the second most important of the functions of the legislature, although one which occupies an increasing amount of parliamentary time as the demands of the positive state continue to grow. The legislature has a third function in giving approval to the financial transactions of government for each fiscal year. This means not only that the details of revenue and expenditure require parliamentary sanction but that the whole process of the national budget is subject to parliamentary approval. Lastly, the function of parliament is to act, as John Stuart Mill said, as the nation's congress of opinions and committee of grievances. The ancient parliamentary maxim of "grievance before supply" has resulted in procedures by which there is opportunity for the venting of grievances before supply is voted. The business of parliament is not only the articulation of grievances but the informed discussion of public issues before decisions are taken. Thus Parliament performs what Bagehot called the educative function of making the electorate aware of the issues confronting the country so that the elector would be adequately informed in casting his ballot.

It will be my purpose to consider how far legislative committees assist in the proper discharge of these various functions. The role in the first can be dismissed at once. A government is responsible to the whole House and, indeed, the responsibility of the Cabinet for policy has been one of the main reasons why the powers of our committees have been severely limited in comparison with, for example, the French or the American system where Committees possess independent powers of initiation. It is in connection with the other functions of the legisla-

-This paper was presented to the Fourteenth Annual Conference of the Institute of Public Administration of Canada, September 5 to 8, 1962, Regina, Saskatchewan. 
ture-legislation, supply, the articulation of grievances, and the "education" of the public-that parliamentary committees have played a part and may in future have a more important role to play.

\section{Definition and Role of Committees}

The essence of a committee, says Dr. Wheare, "is that it is a body to which some task has been referred or committed by some other person or body."1 To this he adds certain other characteristics. The first of these is that a committee is subordinate to the parent body from which it derives its powers and to which it is responsible. The second is size. While there may be a committee of one, we normally think of a committee as comparatively small in size and of course smaller than the body which set it up. The obvious exception to this is the Committee of the Whole but in this case, as Wheare notes, the parent body has turned itself into a committee in order to gain certain procedural advantages. Historically, in the case of the House of Commons it was to escape the eye of the Speaker when he was thought of as a King's man. The device is also used by municipal councils in order to conduct part of their business in private.

Wheare divides committees into six different types according to the functions they perform: committees to advise, committees to inquire, committees to negotiate, committees to legislate, committees to administer, and committees to scrutinize and control. Because of the nature of cabinet government some of these functions are more appropriate to legislative committees than others. Nevertheless, it is useful in looking at a committee to begin by asking what functions it performs or is capable of performing. Thus the Standing Committee on Banking and Commerce of the House of Commons might appear from its title to be a very important committee. But it does not advise, it seldom inquires, it is not in a position to negotiate, it does not administer, nor does it scrutinize and control. It plays a very occasional role in the process of legislation and that is all. The truth of the matter is that many of the standing committees of the House of Commons now bear little relation to the normal flow of business in the House. History has passed them by and no one has thought of a present use for them.

The committee structure of parliament, though perhaps originally designed to expedite or improve the conduct of business, is hopelessly out of date. The business of committees is either to save time or to clarify questions. The present system does neither. There are various reasons for this. Committees have only such powers as the House may confer on them and consider only such business as the House may refer to them. Committees cannot sit, except with special permission, while the House is sitting, and they die when Parliament is prorogued or dis-

${ }^{1} \mathrm{~K}$. C. Wheare, Government by Committee (Oxford, 1955), pp. 5-6. 
solved. They play practically no part in two of the most important and time-consuming functions of the House-financial legislation and ordinary legislation. How has this come about?

\section{Committees Past}

The uses of committees have varied according to the prevailing pattern of politics in each generation. The most important difference in this case has been in the relationship of the government to the legislature. Before the days of responsible government the committee system flowered, as it does generally under a system of separation of powers. A legislative majority unable to control the strings of power will naturally resort to every parliamentary device at hand to harrass and contain the government. One of the most obvious of these is the committee system. The exploitation of committees to inquire, of committees to scrutinize and control, and even of committees to administer is characteristic of the days before responsible government. In Nova Scotia, for example, the allocation of the Road Fund by the Legislative Assembly in committee continued for many years after the grant of responsible government. ${ }^{2}$ In the province of Canada, and later in the Canadian Parliament, a good deal of autonomy rested in two rather unimportant committees, the Standing Committee on Printing, and the Internal Economy Committee of the House of Commons. ${ }^{3}$ These things happened in spite of the fact that one of the obvious consequences of responsible government is the concentration of the allocation of expenditure in the executive. But deeply ingrained habit dies hard.

Even after the first decade of responsible government, party lines were still a little uncertain, so that such bodies as the Public Accounts Committee could flourish without curtailment by the executive. Only after the fall of the first Macdonald government did this period of considerable parliamentary independence of the executive begin to decline. Responsible government undermines parliamentary independence. The fact of the matter is that "the House of Commons lives in a state of perpetual choice: at any moment it can choose a ruler and dismiss a ruler" as Walter Bagehot put it. ${ }^{4}$ That this state of contingent choice can be reconciled with stable government is a consequence of political parties, and the growth of party discipline has meant that the government majority is used to confine and limit any action in the legislature which might weaken the government.

The concentration of power in the executive and the diminution of the power of parliament has not been complete. It is weakened by weak parliamentary majorities, by minority governments which are the conse-

2J. M. Beck, The Government of Nova Scotia (Toronto, 1957), pp. $106 \mathrm{ff}$.

${ }^{3}$ Norman Ward, The Public Purse (Toronto, 1962), pp. $50 \mathrm{ff}$.

4The English Constitution (London, 1928), p. 125. 
quence of the rise of third parties, and it may also be weakened by a widespread distrust of straight party government. Thus, for example, in Western Canada the rise of the progressive movement with its emphasis on constituency autonomy sometimes made it difficult for governments, even with large majorities and the short legislative sessions normal in the provinces, to assert coherent and effective control over persistent rebels in their own parties. It was this relic of progressivism which kept the Aberhart Government in Alberta under constant pressure from the rear throughout the whole of the first legislature in which they held power. An activist back-bench group were even strong enough in 1937 to hold up supply as a means of coercing the government and keeping the legislature in session until their demands were at least partly satisfied. ${ }^{5}$

The power of the old committee system as a device for curbing the power of government and for enlarging the scope of opposition has generally declined since the war. The reason for this is partly the growing professionalism of the public service which has led to the increased strength of rational bureaucratic controls over administration. This in turn has weakened the effectiveness of committees because they were essentially the means for "amateur" criticism of policy through the technique of the calling of witnesses before standing committees (a good example of this is the massive evidence on the workability of social credit before the Standing Committee on Agriculture in the Alberta Legislative Assembly in 1934) or, alternatively, they provided opportunities for the exposure of graft and scandal. If it were true that the eradication of corruption through tighter administrative controls were the end of the matter, then we could contemplate the decline of the committee system with equanimity.

But the truth of the matter is that the growing importance and complexity of public business make it more and more essential that there should exist machinery for the public discussion of complex issues, for the careful consideration of legislation, and for the scrutiny of executivemade regulations. A helpless and frustrated legislature may be a symptom that the public service has the process of government under good control but it is also a sign that steps should be taken to modernize the techniques of legislative scrutiny and criticism. Otherwise, as Professor Kersell reminds us, "expert public servants may become the masters of the people they are employed to serve."

\section{Committees Present}

The flow of public business is now so great, and its nature so comp. 72

$5 \mathrm{~J}$. R. Mallory, Social Credit and the Federal Power in Canada (Toronto, 1954),

John E. Kersell, Parliamentary Supervision of Delegated Legislation (London, 1960), p. 1 . 
plicated, that it can only be handled by bodies with the technical competence and the rational organization to master it. As Dr. Bernard Crick has pointed out:

The novels of C. P. Snow, Professor Parkinson's Law and K. C. Wheare's Government by Committee are all, in different ways, testimonies to the truth that the most important work of central government is conducted not by civil servants or M.P.'s working as individuals, but by committees. ${ }^{7}$

Consider for example any committee within the executive, such as a Cabinet Committee or an interdepartmental committee. It has a defined subject matter in which the various members of the committee have very considerable knowledge and experience. In most cases those attending will have studied the matter beforehand and will arrive fully briefed on the subject. The committee will follow a set agenda circulated in advance in which the priority of items is based on their urgency and importance. The committee will be under the necessity to reach agreement and to report.

Now contrast this with a legislative committee. Many, perhaps most, of its members will lack both knowledge and experience of the subject before the committee. ${ }^{8}$ They will not in general have been very fully briefed on the topic to be discussed, for political parties lack adequate research facilities for such purposes and legislative libraries are not equipped to be of great assistance. The Committee will not have a secretary with expert knowledge, but a committee clerk who at best can assist the chair and the committee in matters of procedure. The time of the meeting will be difficult to arrange because most members have urgent conflicting engagements. There may even be difficulties in reconciling available time with the availability of a committee room. The order of business may be difficult to achieve agreement about and even more difficult to adhere to. Lastly, the work of the committee may be overtaken by events and its business abruptly terminated by prorogation.

Some of these difficulties are insoluble. A legislative committee is necessarily made up of both opposition and government members, and its agenda and composition are the consequences of decisions by the "steering group" which must reach some workable inter-party compromise. No matter how narrowly technical the subject before the committee may be and how non-partisan its conduct, the members of the committee will be party men and they are bound to differ about the objectives of public policy.

${ }^{7}$ Bernard Crick, Reform of the Commons. Fabian Tract No. 319 (London, 1959), p. 13.

${ }^{8}$ Cf. Norman Ward, op. cit. "The turnover was so great that after one wholesale change the chairman inadvertently referred to 'the last committee' as if it had been a separate body, and newly appointed opposition members, in particular, showed a disposition to fight again battles already lost by their predecessors." p. 265. 
Nevertheless there are difficulties which can be remedied. If those in control of parliamentary business really wished to get business before committees, without waiting too far into the session, they could do so. If legislatures saw genuine benefit in committee work, they would provide more amply for committee space, for committee staffs, and more generously for assistance to individual members in research and information facilities. While this is a general point relating to the efficiency of Members, I think that it would be a better expenditure of public funds if a good legislative reference service could be provided in Parliamentary and legislative libraries, rather than the present tendency to allot increasing staff at public expense to the offices of opposition party leaders.

One of the major problems with committees is to grasp clearly what it is that they can do to increase the efficiency of the legislature. This may require a general overhaul of the existing committee structure as well as some modification in the rules governing the stages of legislation. At present the antiquated committee system is cumbersome and suspect because it offers little except opportunities for dilatory tactics.

\section{Committees to Legislate}

The Standing Orders of the British House of Commons now provide that public bills (other than appropriation bills, taxation bills, or bills to confirm provisional orders) are taken in Standing Committee "unless the House otherwise order." Bills of first-class constitutional importance and often other bills of intrinsic importance will normally be sent to Committee of the Whole for the committee stage. The principal reason for this rule is to expedite the business of the House, since as many as five standing committees may be dealing with bills "upstairs" at the same time. There are obvious limits to the multiplier effect of this procedure, since all bills still have to be funnelled through the bottle-neck of Report and Third Reading. Nevertheless, the procedure has great advantages. The standing committees, though non-specialist, are large enough to be an effective microcosm of the Committee of the Whole, and the party whips are able to add a substantial number of members and withdraw an equal number in order to stock each committee with the party experts on any particular bill. Not only is time saved but there can be little doubt that a more business-like atmosphere can operate in the committee-room than on the floor of the Chamber.

In every session of the Canadian Parliament a substantial portion of the bills introduced dies on the way. In some cases this may be deliberate, since opinion has longer to harden on the merits of a bill if it has been before the House in more than one session. But a great deal of the mortality is caused by a combination of bad management of the Government's legislative program and sheer lack of time. The use of Standing Committees in order to reduce time spent in Committee 
of the Whole would reduce such wastage, save the time of the House, and lead to more effective consideration of bills. There are those who may object to this proposal on the ground that Canadian conditions are sufficiently different that the introduction of procedures from the British House may not produce the desired result and that slavish imitation of Westminster is no longer desirable in Canada. Our legislatures have developed independently and it would be better if we found procedural reforms consistent with the genius of our own institutions.

To this the best answer is to point out that the practice I am suggesting already exists-and has existed for many years-in at least some provincial legislatures and it has been developed in a form which is consistent with our own parliamentary history. Furthermore what is advantageous for legislatures of fifty to a hundred members should be more valuable for a Chamber of two hundred and sixty-five.

Consider, for example, the "two-committee system" in Nova Scotia. There all bills are routed by the Speaker to one of two standing committees. As Professor Beck describes it, "the division normally follows that of the statute book-public bills go to the Law Amendments Committee and all others to the Committee on Private and Local Bills. Yet the system is flexible for, when a bill relating to a particular area or interest involves considerations of the type presented by public bills, it may be referred to the former committee." through standing committees they are then quickly put through the Committee of the Whole. A similar system appears to operate in Quebec and possibly in other provinces as well.

This procedure also has the advantage that Canadian Standing Committees have the power to hear witnesses, so that when desired a very thorough examination of a bill is possible. This procedure is, of course, already open to the Canadian House of Commons, but in present practice it has two weaknesses. In the first place it is unusual and is resorted to normally for controversial or exceptionally complicated bills, such as the Unemployment Insurance Bill in 1940 or the periodical revisions of the Bank Act, so that reference to a Standing Committee is a signal to interested parties that the passage of the bill will lead to a good deal of argument and delay. That is no doubt one of the reasons why the Government resisted so strongly the attempt by the Opposttion to refer their little bill to dismiss Mr. Coyne to the Standing Committee on Banking and Commerce in 1961. The second objection to the present use of the procedure is that the number and composition of the present Standing Committees has neither rhyme nor reason in relation to the legislative process. It should not be exceptionally difficult to scrap the present "subject-matter" committees and replace them with about four committees which could together handle all types of legislation.

${ }^{9}$ Beck, op. cit., pp. 278-80. 


\section{Scrutiny of Delegated Legislation}

One of the most obvious gaps in our parliamentary machinery is a scrutiny committee to oversee delegated legislation. The comparatively short sessions of Canadian legislatures have doubtless always made it desirable to legislate in rather general terms and to leave rather wide powers to the executive to flesh out the act by order in council. Such action is characteristic of emergency legislation, while the growth and complexity of welfare legislation has meant an enormous increase in the rulemaking powers of the executive. These regulations are not always or necessarily simply the filling-in of non-contentious interstices in the act by order in council. Quite often the enabling clauses are wide enough to give power to legislate on important matters of principle. This is not a new problem or a problem unique to Canada. Thirty years ago the Committee on Ministers' Powers in the United Kingdom considered the whole question of delegated legislation and, while admitting the necessity of flexibility, set forth a number of kinds of legislation which are inappropriate in the hands of the executive, save temporarily in an emergency. They are (i) the power to legislate on matters of principle and even to impose taxation; (ii) the power to amend acts of Parliament; (iii) conferring such wide power on a Minister that it is impossible to determine what limit Parliament intended to impose; (iv) where Parliament has in effect conferred unlimited powers by forbidding control by the Courts. ${ }^{10}$ These principles have been a powerful weapon in the hands of critics of delegated legislation ever since. In addition, there are a number of checking procedures in the United Kingdom which limit the legislative power of the executive. Some executive orders are valid only after they have received parliamentary sanction. Others may be rescinded if a motion is carried against them in Parliament. In addition, all delegated legislation is considered by a select committee of the House of Commons, called the Statutory Instruments Committee. Superficially the powers of the committee are very limited since they cannot consider the policy embodied in an order but only its form. They are required to report on orders which offend against a number of criteria which in effect boil down to those laid down in the Report of the Committee on Ministers' Powers. The Committee merely reports to the House. However, its report may be grounds for a motion or prayer to rescind an order. ${ }^{11}$

How far do any of these forms of parliamentary review exist in Canada? The foundation has been laid but that is all. Delegated legislation differs from ordinary legislation in that it is not preceded by prior public discussion by representative persons. The opportunity for subsequent parliamentary review is therefore a necessary means of preserving

10Report, Cmd. 4060/1932, p. 31.

${ }^{11}$ These are fully discussed in, e.g., Kersell, Parliamentary Supervision of Delegated Legislation, and Wheare, Government by Committee. 
the usual constitutional checks on the executive. Regulations made by the executive are not of course regulations made without debate. The committees of officials and of ministers who are likely to discuss a proposed regulation before it is promulgated are a highly sophisticated machinery of debate and discussion, which is likely to anticipate and disarm most kinds of criticism in advance. But debate and discussion which take place secretly in the womb of the executive are no substitute for public debate and discussion in a democracy.

The Regulations Act merely provides that regulations having a legislative intent shall be tabled in Parliament, published in Part II of the Canada Gazette and subsequently incorporated in Statutory Orders and Regulations. Nothing in particular is done to ensure that they do in fact receive parliamentary scrutiny and there is no place in the time table of the House of Commons to ensure that there is an opportunity to discuss them. ${ }^{12}$ When these points were raised in the debate on the Regulations Bill, the then Prime Minister rejected the idea of a scrutiny committee, partly on the erroneous ground that there is much more careful scrutiny of draft orders in council in Canada than there is of departmental regulations in the United Kingdom and partly on the ground that the scope of the committee would be limited to consideration of the form of regulations and "we do not believe that would fit our situation."13

This last may have some point. The rigid exclusion of policy considerations from the purview of the scrutiny committee in the United Kingdom is open to criticism. However, in Canada it has been much more difficult to confine legislative committees within such narrow bounds, and there can be little doubt that a Canadian scrutiny committee, however its terms were drafted, would be likely to range more widely. A standing committee to review all delegated legislation as to form and to report to the House would be highly desirable. Furthermore, it would be equally desirable that Standing Orders be modified to set aside a half hour at the end of each sitting day in which members could move motions against standing orders and raise similar matters in the same way as this is done in the United Kingdom.

Such a scrutiny committee would be confronted by a complex and highly technical task which could hardly be undertaken without expert assistance. The success of the United Kingdom Committee has depended to a great extent on the work of the Parliamentary Counsel to the Speaker, who plays a role in relation to the Committee somewhat similar to that of the Auditor General to the Public Accounts Committee. ${ }^{14}$ Whether this committee should be in the Commons or the

12See J. R. Mallory, "Delegated Legislation in Canada," Canadian Journal of Economics and Political Science, vol. 19, 1953, 462-71; reprinted in J. E. Hodgetts and D. C. Corbett, Canadian Public Administration (Toronto 1960), pp. 504-14.

${ }^{13}$ Canada. House of Commons Debates (unrevised), May 31, 1950, p. 3040.

${ }^{14}$ Cf. Kersell, op. cit., pp. 53 ff. 
Senate is perhaps debatable. The Senate's record in this kind of hardworking and unspectacular committee work is a good one and there is good reason to urge that this should be a senate function as it is in Australia. The main reason for making this the work of a Commons committee is that it might have great educative value to Members. However if, as suggested above, Commons committees are to play an increasing role in legislation and financial control, there are strong grounds for making this the work of a Senate Committee.

\section{Financial Control}

The House of Commons now has the two major committees for financial control over government operations in the Standing Committees on Public Accounts and on the Estimates.

The Public Accounts Committee, after an uncertain middle life, seems now to be on the way from its earlier preoccupation with dirtdigging towards the less spectacular role of backing up the Auditor General in his efforts to clarify the presentation of the Public Accounts and generally to bring about improvements in government accounting procedures. As Professor Ward points out, effective control over waste and extravagance is now no longer susceptible to the uncertain and variable efforts of a legislative committee. The trend, begun with the Consolidated Revenue and Audit Act, and carried much further with the Financial Administration Act, has now made this a clearly recognized function of the executive. ${ }^{15}$ Whether, under the circumstances, the Committee's work would be better served by a smaller body, meeting in camera, is worth serious consideration.

The Estimates Committee is of recent origin and it may not yet be possible to reach firm conclusions on its effectiveness or even on its precise role. It can be said that the Committee is developing into an extension of the Committee of Supply. Earlier fears that it would merely duplicate the work of that Committee are not, I think, justified. Whether it actually saves the time of the Committee may be a matter of debate. There have been occasions when Estimates, after full discussion in the Estimates Committee, have gone through the Committee of Supply very quickly. ${ }^{10}$ There are other cases where no time seems to have been saved at all. ${ }^{17}$ However, the Committee should not be judged on this criterion, since this was never intended to be its primary function. Its greatest value is to "educate" the Committee of Supply by providing on the record a considerable stock of systematic information which would be more difficult to present in Committee of the Whole. The Estimates

15Ward, The Public Purse, pp. $170 \mathrm{ff}$.

$16^{\prime \prime}$ These estimates have been previously examined by a Committee which has worked many hours going into them in detail; otherwise, I am sure, Mr. Chairman, we would not have been able to get them through so quickly. Perhaps that should be on Hansard." Canada. House of Commons Debates, 1958, p. 3243.

17Ward, op. cit., p. 277. 
Committee is able to hear evidence from officials and others; it is therefore easier to lay well-organized material before it and have this material elaborated under questioning. In the Committee of Supply, the Committee has to deal with officials through the medium of the Minister and, as government business has become increasingly complex, it has been harder to make discussion in Supply both thorough and effective. Armed with the proceedings of the Estimates Committee, the Members are in a better position to discuss questions in Committee of Supply. Since 1958 the Committee's proceedings include such materials as charts and statistical data which have been presented to them which are likely to become a mine of useful information for the future. ${ }^{18}$

\section{Scrutiny of Crown Corporations}

Some regular parliamentary scrutiny of the normal departments of government is possible by consideration of the Estimates in the Committee of Supply. Such regular opportunities do not exist with regard to most crown corporations. No doubt this was deliberate. As Professor Hodgetts has observed, "Parliament's role in relation to the public corporation in Canada has not been clearly assessed in the past because of the fear of those enthusiastic supporters of managerial autonomy that parliamentary 'interference' would spell disaster to the enterprise."19 Yet the difficulty is, as R. B. Bennett put it in 1934, that we have not been able to devise any equivalent to the annual shareholders' meeting in which the directors of enterprises must account to the ultimate owners. $^{20}$ Nevertheless, some crown corporations, partly because of the way in which their operations touch directly on the public and partly because they are forced to return repeatedly to Parliament for funds, have a long history of full exposure to parliamentary committees. The examples that spring to mind are the C.N.R. and the C.B.C. While it is true that the senior officers of these bodies spend so much time in parliamentary committee rooms that it has occasionally seriously impaired their ability to run their undertakings, the results of this have been on the whole good. For there is a careful scrutiny which ensures that these bodies are susceptible to parliamentary control.

The trouble with the present parliamentary scrutiny of crown corporations is that it is highly selective and tends to fall most heavily on those most vulnerable to pressure from powerful interest groups which have persistently sought to destroy them. Parliamentary review should be on a more systematic basis if it is to do more good than harm. I do not think that the best way to do this is through a standing committee on

${ }^{18}$ See Sant Parkash Singh, The Canadian Committee on Estimates (unpublished M.A. Thesis, McGill University, May, 1962).

19 "The Public Corporation in Canada" in W. Friedmann (ed.) The Public Corporation: A Comparative Symposium (Toronto, 1954), p. 84.

${ }_{20}^{2}$ Canada. House of Commons Debates, 1934, p. 839. 
crown corporations. There are too many of them and the experience of this type of committee in the United Kingdom is not wholly encouraging. Instead, I should prefer that a rationalization of parliamentary committees would leave room for scrutiny of crown corporations.

\section{Committees to Investigate}

Investigation in this country has increasingly fallen into the hands of royal commissions, perhaps on the grounds that such bodies are more impartial and also unrestricted by the arbitrary time limits which affect parliamentary bodies. ${ }^{21}$ There are, however, questions which legislative committees can usefully consider. There are, first, broad policy questions with a view to legislation and, second, investigation of particular operations of public policy. This is really a form of scrutiny over the executive but it takes the form of post hoc inquiry.

When major policy problems are in the air, there is a great deal to be gained by a well-organized public discussion of the issue and the alternatives. Our usual recourse in this country is to refer such questions to royal commissions but I am not sure that royal commissions are always the best agencies to pursue these inquiries. For one thing, royal commissions are often chaired by judges and it is usual for them to have legal staffs and to pursue their inquiries through the adversary method which the courts have developed to get at the truth. This is excellent when the truth can be got at, and particularly useful when the object of the inquiry is to establish facts from which decisions can then be made. But in the realm of public policy facts are not often simple and straightforward. What is really important is to allow interested parties their opportunities to present their cases and to confront the public with the considered but often conflicting views of the experts. If the object of the inquiry is legislation, then much can be gained by placing the inquiry in the hands of experienced legislators.

Two recent examples of useful legislative enquiries of this type come to mind. One was the select special committee of the Ontario legislature which began in 1957 an exhaustive inquiry into the pattern of labour legislation in Ontario with a view to its consolidation and revision. The other was the more recent Senate Committee on Manpower and Employment. When these Committees provide themselves with research staffs and arrange to hear the testimony of qualified experts, they are able to bring together a unique body of valuable material which is essential if wise legislation is to result. Furthermore, the educative effect on members of the committee is such that a body of informed parliamentary experts in all parties is built up so that debate in Parliament in future will be much more effective. I urge that in the future when governments are considering public inquiries they should consider

21 The Stevens Committee on Price Spreads was turned into a royal commission in 1934 to continue its deliberations without interruption. 
carefully the legislative committee as an alternative to the royal commission. When they choose the former, they should also ensure that the committee is provided the research assistance and the encouragement to conduct a thorough inquiry. Needless to say, such inquiries will work best in areas which are rather technical and on which there is not hot controversy between the parties. For example, banking and monetary policy might in quieter times be an excellent topic for legislative inquiry but in the light of events in the last year a legislative inquiry would probably be overlaid with essentially partisan issues.

There are also occasions when the suspicion that something has gone wrong in administration may lead to a parliamentary inquiry, as when the House Agriculture and Colonization Committee inquired into the circumstances of the foot-and-mouth epidemic in 1952. There were a large number of western M.P.'s who had both interest in and considerable knowledge of the problem and the question was one which vitally concerned every member from an agricultural area. The members were therefore unusually well-qualified to sit on such an inquiry and the mass of evidence that came out was extremely valuable to them as parliamentarians.

Very few of those who have considered the problem in recent years appear to think that parliamentary inquiries should be encouraged. Professor Hodgetts, for example, in his discussion of the role of Royal Commissions, recites all of the usual objections to parliamentary committees, including their uncertain life-span and their tendency to generate more heat than light but he does admit that "whenever problems are recurrent the device of legislative standing committees ought to be used." ${ }^{22}$ I go much further. In its present state, the House of Commons represents a considerable misuse of resources. Far too few members of parliament are able to have any constructive role in the process of government. This not only frustrates them. It also fails to give them the experience and the knowledge which committee work would provide.

\section{New Standing Committees}

The present gaggle of Standing Committees should be abolished and replaced by a simpler committee structure. Some of the older and relatively inactive committees that relate to the affairs of the House such as Privileges and Elections would of course remain. So would those whose functions are readily adapted to present needs, such as Public Accounts. But such committees as Veterans' Affairs and Banking and Commerce should be abolished and replaced by at least four standing committees. A tentative functional division of these new committees could be Trade and Commerce, Communications, Health and Welfare, and Defence and External Affairs.

22"The Role of Royal Commissions in Canadian Government," in Hodgetts and Corbett, Canadian Public Administration, p. 481. 
To these all bills should stand referred after second reading, unless the House otherwise order. The Committee of the Whole would continue to take these bills after they had been reported out of standing committee. It is conceivable that this would not reduce the length of proceedings in Committee of the Whole; but this seems unlikely, for full discussion of each clause would be possible in Standing Committee.

Furthermore, the estimates of the relevant departments and the reports of crown corporations might also be referred to these committees before being reported out of the Committee of Supply. This would eliminate the Estimates Committee but, since its functions have been so much an extension of the work of the Committee of Supply, and since identical work has been done by the External Affairs Committee, this would be a more rational way of allocating the work. It will be noticed that there is some similarity between this proposal and that advanced by Dr. Crick and an even closer similarity to the proposals of Messrs. Hanson and Wiseman for improvement in the procedure of the British House of Commons. ${ }^{23}$ Because of the difference between the committee structures in the two countries, I have suggested that standing committees should do this work. The purpose is the same as that urged on the Select Committee on Procedure in the United Kingdom by Messrs. Hanson and Wiseman who "believe that much of the frustration experienced by the back-bencher in the House of Commons . . . is due to the incapacity of the House, as at present organized, to exercise more than a capricious and sporadic supervision of the administrative function."24

In suggesting that the functions of committees to legislate and committees to scrutinize the administration be combined in a new and limited number of standing committees, I may have overloaded them and invited even greater parliamentary delay and confusion than before. It might have been better to suggest two sets of committees, with the ones engaged in legislation rather larger (50-60) than the scrutiny committees which might be half the size. But the Canadian House of Commons is a small chamber which cannot generate very many committees which are to function at the same time. The experience of the provincial legislatures, with admittedly much smaller legislative loads, suggests that both functions can be discharged by the same committees.

This system is likely to be an improvement only if there is the will to work it shown by intelligent planning and close cooperation among the House Leaders. It would also lead, it is hoped, to greater refinements in the means of controlling parliamentary time. Above all, it might reduce the tedium of proceedings in the House itself.

\footnotetext{
23Bernard Crick, Reform of the Commons, p. 37; A. H. Hanson and H. V. Wiseman, "The Use of Committees by the House of Commons," Public Law, Autumn, 1959 , pp. 277-292.

24 Hanson and Wiseman, loc, cit., p. 278.
} 